\title{
POLITICS, THE RULE OF LAW, AND THE ROLE OF THE CRIME OF AGGRESSION: A RESPONSE TO KOH AND BUCHWALD
}

\author{
Tom Dannenbaum*
}

In this essay, I take up two concerns raised by Harold Koh and Todd Buchwald in their critique of the Kampala amendments on aggression: what they term "proxy prosecution" and the notion of aggression as a uniquely political question. I also take issue with the argument in Alain Pellet's response on attacks by nonstate actors.

These areas of contention notwithstanding, there are important issues on which I think that Koh and Buchwald get it right. In forthcoming work, I argue that the object and purpose of the criminalization of aggression precludes an interpretation of Article 8bis of the Rome Statute that would include humanitarian interventions not authorized by the Security Council. ${ }^{1}$ Nonetheless, the failure to make this textually explicit at Kampala was a mistake that the authors are correct to lament. Similarly, they accurately identify the ambiguities in the provisions on the amendments' entry into force as an entirely avoidable defect that creates unnecessary confusion. These important points notwithstanding, the article takes some misleading positions on the politics of the crime.

\section{Prosecution by Proxy}

In a passing comment, Koh and Buchwald raise alarm about the possibility of what they term "'proxy' prosecutions of state officials for supporting actions of another state that was not subject to the amendments."'2 They use the term to emphasize a particular reading of the "opt out" provision in Article 15bis(4), but it is a revealing choice of words, which encapsulates their broader posture.

The term evokes an image of prosecutors bent on condemning countries and leaders outside of their jurisdiction by indicting defendants who are mere stand-ins for the main target. The subtle implication is that those defendants might not even warrant the International Criminal Court (ICC)'s attention were it not for opportunity to express that vicarious rebuke. Quite apart from revealing a view of the integrity of ICC prosecutors that stands in significant tension with the United States' willingness to empower precisely those actors to prosecute members of the Sudanese and (erstwhile) Libyan regimes, the term implies a disturbing ordering of priorities.

It goes without saying that the conviction of one individual cannot itself entail the criminal guilt of those not present, including even those with whom the convict collaborated in perpetrating the crime. In that sense, the term "proxy prosecution" seems designed to agitate rather than to illuminate. The real concern is presumably less about the legal implications for individuals not present than it is about the embarrassment that would be

\footnotetext{
* Lecturer in Human Rights and the Director of the MA in Human Rights at University College London.

Originally published online 02 March 2016.

1 Tom Dannenbaum, Why Aggression is a Crime and Why it Matters (forthcoming).

${ }^{2}$ Harold Hongju Koh \& Todd F. Buchwald, The Crime of Aggression: The United States Perspective, 109 AJIL 257, 292 (2015).
} 
caused to the coalition state not subject to the amendments. Koh and Buchwald are hardly alone in placing great weight on preventing such embarrassment, but in a world of widespread interstate cooperation, this sets the wrong priorities.

The limited international doctrine on protecting states from hostile rulings in external courts does not extend to this context. The ICJ's "indispensable third party" rule has been applied narrowly and is specific to the context of a court with jurisdiction over states ruling directly on the rights of a state not party to the litigation. ${ }^{3}$ Official immunity, which protects states' reputations in the context of legal action against individuals, cannot be interpreted as extending to the protection of states other than that of the official in question, and is anyway of dubious status in the context of international crimes charged before international courts. ${ }^{4}$ And extending the doctrine of par in parem non habet imperium - the principle that equals have no sovereignty over each otherwould also be inappropriate. ${ }^{5}$ Rather than preventing the wrongful exercise of sovereignty over a foreign state, the invocation of that principle in this scenario would create a foreign veto over the home state's capacity to hold its own public officials to account for criminal wrongdoing, whether in domestic court or in an international court to which it has delegated such authority. ${ }^{6}$

Notably, worries about embarrassing other states have never been considered sufficiently weighty to block non-refoulement evaluations, even though such judgments often entail assessments of the international law violations of the destination state. In an important development, that privileging of the rule of law over concerns about embarrassment has recently been extended to other contexts. Specifically, the European Court of Human Rights has ruled that European states violated their human rights obligations through hosting and enabling the wrongful conduct of American agents during the CIA's secret rendition and enhanced interrogation program. ${ }^{7}$

The worry about "proxy prosecutions" seeks the reversal of this positive step, asking for the nonprosecution of the leaders of U.S. coalition partners despite the fact that such prosecutions:

- would occur under procedural standards and in a forum to which the states of those leaders have consented for precisely this purpose,

- would charge a crime whose criminality is rooted in universal jus ad bellum standards,

- would not have any direct legal implications for the United States or its nationals,

- would occur before a court that the United States deems sufficiently credible to prosecute sitting heads of state in nations that have never signed, let alone ratified, the Rome Statute,

- and would fall outside existing international doctrines protecting third states' interests in litigation.

Were the court, or even the states in question (via article 15bis(4)), to accept this prioritization, it would mark a lamentable step backwards.

${ }^{3}$ East Timor (Port. v. Austl.), 1995 ICJ REP. 90, para. 28 (June 30); Case of the monetary gold removed from Rome in 1943 (It. v. Fr.), 1954 ICJ REP. 19, 32 (June 15).

4 See, e.g., Case Concerning the Arrest Warrant of 11 April 2000 (Dem. Rep. Congo v. Belg.), 2002 ICJ ReP. 3, para. 61 (Feb. 14); Prosecutor v. Taylor, SCSL-2003-01-I, Decision on Immunity from Jurisdiction, para. 51 (May, 31, 2004).

${ }^{5}$ Koh and Buchwald invoke the doctrine to argue against aggression prosecutions in a different context, namely prosecutions in domestic courts of foreign leaders. Koh \& Buchwald, supra note 2, at 275.

${ }^{6}$ This is not to say that domestic courts lack the discretion to refuse to hear cases implicating foreign states in this way, much as it

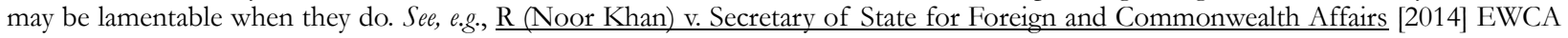
(Civ) 24 .

7 See, e.g., El Masri v. Former Yugoslav Republic of Macedonia, 2012-VI Eur. Ct. H.R. 263; Al-Nashiri v. Poland, Eur. Ct. H.R., App no. 28761/11 (July 24, 2014). 


\section{Politics and Crime}

In another claim worthy of reflection, Koh and Buchwald argue that aggression's uniquely "politically charged" nature makes its adjudication "different in kind" from that of any of the other crimes covered in the Rome Statute. ${ }^{8}$

An important element of this argument is the claim that the definition of the crime is ambiguous. ${ }^{9}$ Of course, at the margins, this is true of any crime, domestic or international. ${ }^{10}$ What seems to worry Koh and Buchwald is not that ordinary ambiguity at the margins, but what they view as a broad grey area that blurs not just the criminal and noncriminal, but the line between acts that are criminal and acts that are necessary to the defense of lives or a political community and thus the right (and not merely permissible) thing to do.

Article 8 bis combats this by providing that only manifestly illegal wars qualify as criminal, thereby creating a strong presumption of noncriminality for grey area cases. This is similar to the approach taken in Article 8(2)(b)(iv) on disproportionate attacks.

Rather than acknowledging the significance of this threshold in addressing the complaint of ambiguity, Koh and Buchwald bemoan the unclear connection between the "manifest violation" requirement and the "character, gravity and scale" elements of aggression. ${ }^{11}$ Although they are right that this aspect of the provision is poorly drafted, the notion that it creates a genuine danger of prosecution for "the firing of a single bullet that flies across the border" is far-fetched, particularly in light of the ICC's broader gravity threshold. ${ }^{12}$

It seems then that the real concern is rooted in the politics of war. The idea seems to be that, given that states on either side of any war tend to label their opponent the aggressor, a convicted leader's state and its people would be unlikely to accept the verdict. ${ }^{13}$

This, however, is neither universally true, nor an accurate representation of the distinctiveness of aggression. A war of aggression can stimulate overwhelming domestic opposition, as was the case in many states involved in the invasion of Iraq, potentially even prompting a desire among some to see the leader punished for sending their loved ones to die without justification. ${ }^{14}$ Conversely, domestic populations whose states fought what was considered an existential war often deem those of their leaders prosecuted for jus in bello crimes to be war heroes. ${ }^{15}$

Perhaps the worry is that a finding of individual aggression would necessarily implicate the state's own responsibility in a way that other international crimes do not, and that this would exacerbate political difficulties. But there is an identifiable category of genocide, crimes against humanity, and war crimes that also implicates the state-those committed in an official capacity. And yet, in Article 27, the Rome Statute explicitly precludes official immunity as a barrier to prosecution.

${ }^{8}$ Koh \& Buchwald, supra note 2 , at 260.

${ }^{9} \underline{I d}$. at $257-258$.

${ }^{10}$ Consider, for example, the debate about whether the killing and displacement campaign in Darfur constituted genocide. SecretaryGeneral, Report of the International Commission of Inquiry on Violations of International Law and Humanitarian Law and Human Rights Law in Darfur, UN Doc. S/2005/60 (Jan. 31, 2005); Prosecutor v. Al Bashir, ICC-02/05-01/09, Second Warrant of Arrest for Omar Hassan Ahmad Al Bashir (July 12, 2010).

${ }^{11}$ Koh \& Buchwald, supra note 2, at 270-271.

${ }^{12} \underline{I d}$. On the general gravity threshold, see Rome Statute of the International Criminal Court art 17(1)(d), July 17, 1998,2187 UNTS.

${ }^{13}$ Koh \& Buchwald, supra note 2, at 277.

${ }^{14}$ Richard Norton-Taylor \& Nicholas Watt, Families of dead soldiers threaten Blair with court, GuARDIAN, May 4, 2005.

15 See, e.g., Selma Milovanovic, Hero's welcome for Serb accused of war crimes, AL JAZEERA, Nov. 12, 2014; OrGANIZATION FOR SECURITY AND CO-Operation IN EUROPE, ATTITUdes TOWARDS WAR CRIMES ISSUES, ICTY AND THE NATIONAL JUDiCIARY 30, 35, $41,43-45$ (2011). 
Two further factors are relevant in evaluating the risk of destabilization. First, except in the context of a Security Council referral, the Court's jurisdiction over aggression will extend only to leaders of states that have consented to that jurisdiction. Second, Koh and Buchwald disregard entirely the political consequences of ignoring the victims of aggression. Jus-in-bello-sanitized invasions, for all their International Humanitarian Law compliance, inflict an enormous human toll on the people of the attacked state. This toll can be especially hard to take when the violence is extremely one-sided, as might be the case in a war in which one side limits itself to drone operations.

A final aspect of the politics of aggression relates to the authors' claim that the Kampala amendments disrupt and undermine the Security Council's exclusive competence to determine whether there has been an act of aggression. In considering this, it is important not to lose sight of the significance of the Security Council's role as things stand. Article 15bis guarantees that the Council will have an opportunity to assert its jus ad bellum determination prior to any judicial analysis, and Article 16 empowers the Council to defer any prosecution that threatens international stability.

For Koh and Buchwald, however, this is not enough. They want the silence of the Security Council to preclude ICC investigation, just as it precludes the use of nondefensive force. This goes too far. The need for affirmative authorization in the case of force is explicit in the combination of Article 2(4) and Chapter VII of the UN Charter. For other issues within the Security Council's remit, when the Council decides not to act, that opens the door to other entities to do so with the consent of the states involved. ${ }^{16}$ In other words, unless there is a prima facie ban on the action in question, Security Council silence ought to be understood to be permissive, not prohibitive. Any other posture would grant extraordinary power not to the Council as a corporate agent, but to each individual permanent member.

On this point, it is puzzling that Koh and Buchwald fail to grapple with the Council's record of gridlock. This is particularly jarring in light of Koh's contention elsewhere that the Security Council's failings are so grave that it is appropriate for states to use force unilaterally in situations other than self-defense. ${ }^{17}$ In other words, having argued elsewhere that Security Council silence can be considered permissive on the one issue on which the Charter provides precisely the opposite, Koh argues here that it would be a severe danger to world order if an international, independent court were to accept Security Council inaction as an opportunity to review the use of force by a state that consented to its jurisdiction.

Attacks by Nonstate Actors

A final point worthy of note in the exchange prompted by Koh and Buchwald is Alain Pellet's claim that the Kampala drafters erred in excluding attacks by nonstate actors from the scope of the crime. ${ }^{18}$ To my mind, this misses the point of criminalizing aggression.

Aggression criminalizes the wrong of inflicting death and violence without the justification of responding to the infliction of such violence or the immediate threat thereof. ${ }^{19}$ The crime of aggression fills a normative gap, capturing a rare category of unjustified, large-scale killing that is not criminally prohibited by any other

${ }^{16}$ Certain Expenses of the United Nations (Article 17, paragraph 2, of the Charter), Advisory Opinion, 1962 ICJ REP. 151, $163-64$ (Mar. 25).

17 On proposed action against the Assad regime in 2013, Koh condemned those asserting the illegality of such an intervention for taking "a crucial fact that marks the Syrian situation—Russia's persistent, cynical veto—as an absolute bar to lawful action, not as a sign of a systemic dysfunction that bars the U.N. from achieving its stated goals in Syria." Harold Hongju Koh, Syria and the Law of Humanitarian Intervention (Part II: International Law and the Way Forward), Just SECuRITY (Oct. 2, 2013).

18 Alain Pellet, Response to Koh and Buchwald's Article: Don Quixote and Sancho Panza Tilt at Windmills, 109 AJIL 557, 562-563 (2015).

${ }^{19}$ Dannenbaum, supra note 1. 
provision of domestic or international law-namely, the killing of combatants and collateral civilians in an illegal war. Such jus-in-bello-compliant killing is plainly legally unjustified-it is inflicted in the service of an illegal end-and yet its immediate perpetrators are appropriately shielded from liability for that violence for various reasons relating to their nonculpability and the importance of the privileges of belligerency in containing the human costs of war. The criminalization of aggression maintains that shield, while capturing the wrongfulness of the constituent killing by holding the leaders of such wars responsible for inflicting that wrong. It provides otherwise missing criminal law protection to the right to life of combatants and "proportionate" collateral civilians against the wrongful violence of foreign states. Significantly, transnational attacks by nonstate actors are not part of that normative gap. Unlike the violence inflicted on soldiers and collateral civilians in a state aggression, the analogous violence inflicted in an attack by nonstate actors is criminalized in a wide range of ways already. Among others, these include murder, various terrorism offenses, and, in many instances, crimes against humanity.

Of course, the common view, different from the account I have just put forward, is that aggression criminalizes a wrong against states' rights. But on that view, too, it is unclear why transnational attacks by nonstate actors ought to be included in the crime of aggression, given that those attacks are already criminal in the same ways as are the attacks of a domestic rebel group.

My suspicion is that the demand for the inclusion of nonstate attacks is actually stimulated not by direct concern for the scope of the criminal wrong, but by the desire to resolve the ongoing debate about whether states have a right of self-defense against transnational attacks by nonstate actors. ${ }^{20}$ However, there is little reason to believe that the inclusion of nonstate attacks in the crime of aggression would help in this regard.

Despite the International Court of Justice's use of the General Assembly definition of "aggression" in developing its jurisprudence on the concept of an "armed attack," the two terms are plainly textually distinct. ${ }^{21}$ More importantly, the grounds for self-defense and the grounds for criminal liability are not inherently related. The debate on self-defense against nonstate actors has nothing to do with the question of whether states can act defensively against the perpetrators of those attacks. If the defensive action occurs within the state's own borders or on the high seas, the state is clearly entitled to exercise such force. The crux of the self-defense debate relates instead to the conditions under which it is lawful to use defensive force against such a nonstate perpetrator on the territory of a state that did not "send" it to perpetrate the attack. In other words, if there is not a legal right to act defensively against foreign nonstate actors, it is due not to the nonliability of the nonstate actor to defensive force, but to worries about allowing military action in another state's territory when the latter has done little to justify such a significant infringement. Whatever one takes to be the appropriate resolution of that issue (whether the use of an "unable or unwilling" test or otherwise), it has nothing to do with whether the attack itself should be considered to be a criminal aggression.

${ }^{20}$ For just one recent example of the broad range of commentary on the issue, see Monica Hakimi, Defensive Force against Non-State Actors: The State of Play, 91 INT'L L. STUD. 1 (2015).

${ }^{21}$ For the ICJ's use of the definition of aggression, see, for example, Military and Paramilitary Activities in and against Nicaragua (Nicar. v. U.S.), Merits, 1986 ICJ REP. 14, para. 195 (June 27). On distinctiveness, see, for example, Eritrea-Ethiopia Claims Commission, Decision Number 7: Guidance Regarding Jus ad Bellum Liability, para. 5 (July 27, 2007). For an illuminating discussion of how to interpret the ICJ's jurisprudence on this issue in a way that preserves and explains the distinction between "armed attack" and the crime of aggression, see Dapo Akande \& Antonios Tzanakopolous, The International Court of Justice and the Concept of Aggression, in THE CRIME OF AgGression: A COMMENTARY (Claus Kreß \& Stefan Barriga eds., forthcoming). 